\title{
Formulating the 'Alternate Archives' of Produced Locality: Locating the Diasporic Consciousness in the Select Poems of Sujata Bhatt and Debjani Chatterjee
}

\begin{abstract}
The present paper aims to outline the diasporic consciousness in two Indian diasporic women poets namely, Sujata Bhatt and Debjani Chatterjee. The poets' diasporic consciousness is strewn with the nostalgia for lost homes, pangs of homelessness, fractured identity, the disintegrated historiography of displaced individuals, persistent 'post-memory' and continuous struggle to assimilate into the environment of 'hostland'. This assimilation is achieved by transcending the geographical and psychological borders of 'homeland' as seen in the selected poems of Bhatt and Chatterjee. The paper also attempts to show how the poets formulate 'alternate archives' by delineating their discourses of displacement (Hirsch and Smith 2002) of produced locality.
\end{abstract}

Keywords: diasporic consciousness, homeland, hostland, identity, memory, nostalgia

\section{Oblikovanje 'alternativnih arhivov' ustvarjene lokalnosti: Prisotnost diasporske zavesti $v$ izbranih pesmih Sujate Bhatt in Debjani Chatterjee}

\section{POVZETEK}

Članek zariše diasporsko zavest v pesmih indijskih diasporskih pesnic Sujati Bhatt in Debjani Chatterjee. Njuno diasporsko zavest zaznamuje nostalgija za izgubljenimi domovi, bolečina brezdomskosti, zlomljena identiteta, razpadla historiografija dislociranih posameznikov, vztrajni 'po-spomin' in nenehni poskusi vključevanja v 'gostiteljska' okolja. Izbrane pesmi Sujate Bhatt and Debjani Chatterjee kažejo, da je takšno vključevanje mogoče s preseganjem geografskih in psiholoških meja 'domovine'. V prispevku pokažem tudi, kako pesnici oblikujeta 'alternativne arhive' z zarisom diskurzov dislociranosti (Hirsch in Smith 2002) ustvarjene lokalnosti.

Ključne besede: diasporska zavest, domovina, gostiteljsko okolje, identiteta, spomin, nostalgija 


\section{Introduction}

Literature is an interim report from the consciousness of the artist. [...] Literature is made at the frontier between the self and the world, and in the act of creation that frontier softens, becomes permeable, allows the world to flow into the artist and the artist to flow into the world. (Rushdie 1991, 427)

The word 'diaspora', etymologically derived from the Greek verb diaspiero which means 'I scatter between or across', refers to the displacement of people with the same territorial origin from their native homeland. This displacement always carries a sense of alienation, a search for identity and a desire to return to the homeland where the nostalgic memory of home and the reality of hostland intermingle to form an individual's diasporic consciousness. Taken from the Latin word sciare, which means 'to know', consciousness implies a state of perception, awareness and being 'with knowledge'. Considering consciousness within the parameters of human creativity, and knowledge and literature within the socio-culturally constructed and shaped spatial dimensions, consciousness locates and expresses artistic interventions and self-referral quests. In the case of diaspora literature, the reflections, expressions, explorations of certain ethnic, national, psychological and national issues, cultural creolisation and social amalgamation of immigrants or displaced individuals are exposed through a complex and multi-dimensional phenomena called 'diasporic consciousness'. Within the process of acculturation and assimilation, this diasporic consciousness verbalises an individual's sense of alienation, fear, humiliation in a hostland, displacement, memory and nostalgia, hybridity, celebration of homeland, and makes an attempt to maintain an aboriginal identity within the transnational and transcultural corpus. While James Clifford describes diasporic consciousness as "a sense of attachment elsewhere, to a different temporality and vision" and as "a sense of rupture, of living a radically different temporality" (1994, 312-18), Anne-Marie Fortier considers it as a part of a wider movement "where the spatial takes precedence over the temporal in understanding social change" $(2005,182)$. At the same time, Home K. Bhabha and Stuart Hall focus on a displaced individual's "enduring condition of dischronotopicality - of conflict between the way time-space constructions governed subjectivity, community and memory in the homeland and the way they govern subjectivity, community and memory in the place of dispersal-the resulting hybridity" (Peeran 2007, 74). Carol Breckenridge and Arjun Appadurai observe how diasporic consciousness captures the trajectory of the trails of a displaced individual's collective memory that within another time and place formulate new maps of attachment and desire and "compounding the awareness of multilocality, the 'fractured memories' of diaspora consciousness produce a multiplicity of histories, 'communities' and selves- a refusal of fixity often serving as a valuable resource for resisting repressive local or global situation" (Vertovec 2009, 7). By taking into account the discursive terrains of diasporic consciousness propounded by theorists and critics of diaspora and memory studies, this paper aims to unveil the poetic corpus of Sujata Bhatt and Debjani Chatterjee, two noted diasporic Indian women poets writing in English, to explicate how their diasporic chronotopes are governed, shaped and reshaped by the process of dualism and exclusion, producing a double consciousness. 


\title{
2 Imagining the Communities: Diasporic Consciousness and the Poetry of Sujata Bhatt
}

\author{
I am the one \\ who always goes \\ away with my home \\ which can only stay inside \\ in my blood my home which does not fit \\ with any geography. (Bhatt 1997, 63)
}

By showcasing her craft in poetry collections such as Brunizem (1988), The Monkey Shadows (1991), The Stinking Rose (1995), Point No Point (1997), Augatora (2000), The Colour of Solitude (2002) and Pure Lizard (2008), Sujata Bhatt delineates her mastery over her culture, history, and time. Apart from being aware of the manifold persecutions prevalent in society, Bhatt also sketches her eagerness to break all limitations and restrictions of an immigrant woman as she believes that an acceptance or rejection of the homeland cannot form or reduce the whole diasporic experience. It is worth mentioning that Bhatt does not focus on her feelings of displacement from the homeland like other diasporic writers because of an eagerness to carry the memories of her home. Instead, she chooses to deviate from the norm where 'home' can be defined by a geographical location and boundary. She carries her 'home' everywhere and internalises the experience of 'home' that exists beyond any physical bound. 'Home' for Bhatt forms a part of her psyche, disseminating through her system, that is inseparable and incorrigible. For Bhatt home stands at a spatial and temporal distance where "the homing desire" does not necessitate the "ideology of return" (Brah 1996, 194). In these lines from her poem "The One who Goes Away", she writes: "But I never left home/I carried it away/with me-here in my darkness/in myself" (Bhatt 1997, 23); these lines show her ways of carrying home along with her displacement. Thus, home becomes a lived place of desire and experience in her diasporic space of inclusion and exclusion. She seems to echo what Roza Tsagarousianou opines in the following:

The notion of home therefore is much more complex than approaches to diasporas premised on the power of nostalgia would want us to believe. It is intrinsically linked with the way in which the process of inclusion or exclusion operates and is subjectively experiences under given circumstances. $(2004,52)$

Born in Ahmedabad in 1956 and brought up in Pune, Sujata Bhatt moved to New Orleans when her father's work as a virologist compelled her to leave India. At the age of twelve, she moved to Connecticut and all these experiences of moving, shifting and finally leaving India cast an ineradicable impression on her works. For Bhatt, home is something beyond the family rituals, legends, memories, nostalgia, cultures, ethos, customs, relationships and history of the native land. Even the poverty and wretched condition of Ahmedabad and the violence of Hindu-Sikh riots in Delhi find an authentic expression in her poetry. Displacement creates a pain in Bhatt and compels her to memorialise the history of her homeland, and as a result its partition. 
This history of India is best expressed in the section "History is Broken Narrative". In the poem "Partition", the poet maps the pathetic condition of those subjected to the unprecedented geographical divide. Hunger, poverty and alienation were the results of the partition of India in 1947. The poem throws light on the other side of displacement that is involuntary, forced and pathetic. The horrible sounds and pathetic cries of uprooted and homeless people in Ahmedabad railway station arouse the burning question: "How could they/ have let a man/ who knew nothing/ about geography/divide a country?" (Bhatt 2000, 34). Explaining how history is carved out of some narrative in her poem "History is a Broken Narrative", she writes: "History is a broken narrative./Pilka story and see where/It will lead you./You take your language where you get it/or do you" (Bhatt 2000, 40-41). By examining the displacement through the complex process of confluence that neither accepts a facile transplantation nor allows a super imposition of one culture on another, Bhatt tries to draw equality between the narrative of one's diasporic self and the broken narrative of one's history. Describing "history is a broken narrative/where you make your language/when you change it” (Bhatt 2000, 43), she here challenges the conventional concept of linear history that subjects a narrative to the hegemony of homogenisation. Bhatt's history is an assemblage of fragments of narrative that is narrated not in one language, rather in several. Because of Bhatt's staying in an inbetween space or the 'Third Space'- a term used by Homi K. Bhabha, her history "displaces the narrative of the Western nation which Benedict Anderson so perceptively describes as being written in homogeneous, serial time" (Bhabha 1994, 37).

Fragmentation, assimilation and renewal break the narrative of human history, and often a translation may fail to recreate that original aura created by the writer whose work is translated. For this reason, when Bhatt reads translations of the German poet Johannes Bobrowski's works, she misses the poet's actual German sounds, and in her poem "Language" Bhatt expresses this as follows: "In the end, the birch tree/didn't break and the ice melted/ and I could walk beside the river/with your words/a mediated, un-translated in my mouth" (Bhatt 2000, 55). Due to her ambivalent and ever-changing spatial dimension, her dislocated and disintegrated poems challenge the authenticated, unifying and homogenising notions of human history. Here she echoes the words of Homi K. Bhabha, who observes:

The intervention of the Third Space of enunciation, which makes the structure of meaning and reference an ambivalent process, destroys this mirror of representation in which cultural knowledge is customarily revealed as an integrated, open, expanding code. It is that Third Space, though unrepresentable in itself, which constitutes the discursive conditions of enunciation that ensure that meaning and symbols of culture have no primordial unity or fixity; that even the same signs can be appropriated, translated, rehistoricized and read a new $(1994,37)$.

Bhatt's experience of displacement transforms her narrative into a multi-lingual one, and at the same time as a diasporic individual she problematises "your language". She is willing to personalise the foreign language as her 'own', but there lies a gap in between personalising and adopting a language. Dwelling on the liminal space of linguistic-culture, she embodies the hybrid identity, constituting the multitude. Through diasporic consciousness, Bhatt makes her readers aware of dislocation, misfortune, alienation, disengagement and the quest for 
identity. In her poem "Point No Point", she expresses all these feelings as her search for a home in a hostland and her notion of dislocation highlight her desperate condition, and she writes: "Why name a place Point No Point?/Does it mean we are nowhere/when we reach it?/Does it mean we lose our sense/of meaning, our sense of direction/when we stop at Point No Point?" (Bhatt 1997, 11). Language remains one of her safe areas, because through her language she tries to capture her culturally hybrid identity. Her multicultural experiences fail to erase her attachment to and the languages of her homeland. Her hybrid identity creates liminal or in-between space where the negotiation and transition occur to produce the "Third Space.' as Bhabha states: "For me the importance of hybridity is not to be able to trace two original moments from which the third emerges, rather hybridity to me is the 'third space' which enables other positions to emerge" (Rutherford 1990, 211). Bhatt asks a very pertinent question in her Augatora: "what happened when the Gujarati/and the Marathi and the Hindi/I spoke/made room for the English words" (Bhatt 2000, 45). Thus, through these questions mentioning vernacular languages, Bhatt creates a space for herself where home and a diasporic subject's fluid identity can mingle.

Bhatt's language is constantly in flux as she experiences the problems of dual identities, but her identity of 'origin' seems to remain, and she writes: "Constantly changing its colours/as if trying to win me over/with its simmering starlets and blacks/then always slipping out of my grasp - and yet/refusing to go away" (Bhatt 2000, 45). Through her multilingual poetry, Bhatt tries to shed her nostalgia as she always looks forward to asserting her identity and home, and thus her writings often overcome the restraints of negotiable identity and ethnicity. With her 'Third Space' her poems, having no primeval unity or fixity, become ambivalent, where cultural meaning and identity can create new possibilities because "in-between spaces provide the terrain for elaborating strategies of selfhood-singular or communal-that initiate new signs of identity, and innovative sites of collaboration, and contradiction" (Bhabha 1994, 1-2).

Bhatt incessantly attempts to revive her roots while living in the USA. In her poem "Search for My Tongue", she describes her anxiety over losing her mother tongue, Gujarati, and her identity as a Gujarati woman. Realising that it is not easy to use both her native language and English at the same time, she often forgets her mother tongue, but it haunts her in dreams only to encourage her to regain her cultural identity. Imparting a pictorial description of her mother tongue blooming like a flower out of her mouth to cast away her anguish, disaffection and anxiety at losing her roots, Bhatt writes: "it grows back, a stump of a shoot/grows longer, grows moist, grows strong veins,/it ties the other tongue in knots,/the bud opens, the bud opens in my mouth,/it pushes the other tongue aside" (Bhatt 1998, 52).

Issues related to linguistic amalgamation and collision are reiterated in the poem "Augatora" to show how one's native tongue gives one the privilege and opportunity for devout verbalisation, but one's hostland may not provide such an opportunity, and there arises the tension of multilingualism. Issuing from the dualism of 'us-then' to the mutual state of 'both/ and' binaries, Bhatt's identity forms a bicultural hybrid space that is "celebrated and privileged as a kind of superior cultural intelligence owing to the advantage of in-betweeness, the straddling of two cultures and the consequent ability to negotiate the difference" (Hoogvelt 1997, 158). The poet symbolises her native language as an eye-gate which can measure the 
sun and welcome the sunlight. Here the sun symbolises her roots, culture, ethos and identity. Thus Bhatt writes: "Keep an eye on the house/Keep an eye on the child/Don't let the child fall out of the window/Don't throw your house out of the window" (Bhatt 2000, 16). Her poems constantly convey the angst and anxiety of a diasporic individual, who sustains the pain of a fractured identity emerging from the loss and struggle to gain, regain and retain her stand. But at the same time, she tries to resist by using code-switching or language alteration in her poems.

Bhatt begins to clarify her diasporic aesthetic to acknowledge her cross-cultural and multilingual interconnectedness which create a cosmopolitan space. Symbolising the analogy between linguistic and cultural practice, her poetry echoes Steven Vertovec's concept of "xenophilia or penchant for diversity" that elaborates the fact that how "the experience of living in conditions of diaspora, or in fact, engaging in transnational life spread across two or more global settings, exposes individuals to cultural differences that may give rise to such cosmopolitan views" (Vertovec 2010, 64). Being multicultural and multilingual in nature, Bhatt's poetry produces a cosmopolitan space where hybridity and multiple identities are embedded to create a structure based on "an orientation, a willingness to engage with the other $[\ldots]$ an intellectual and aesthetic openness toward divergent cultural experiences" (quoted in Vertovec 2010, 64). For Bhatt, the discourses of history and language are interrelated, and it is through the assimilation of pieces of language that history is constructed. Experiencing incapacitation after witnessing the history of India that ruptures the narrative of different regional languages, she dreams of a nation where people will value the language they use. Though her English language finds a suitable space in her consciousness, this foreign language cannot replace the native ones. While staying in an alien land, Bhatt dreams of her homeland and utters in an optimistic voice: "It will give you time/time to gather up the fallen pieces/of your language - one by one/with your mouth, with your mouth - you need time/to pick up the scattered pieces of your language" (Bhatt 2000, 40).

Migration to another land often compels Bhatt to change her perspectives, and at this juncture her dire need to construct a 'home' pushes her to try and adjust to the customs, languages, ethos and culture of the alien land. For example, her poem "Jane to Tarzan" delineates how Jane's world is changed by Tarzan, and Tarzan takes everything out of Jane. Jane utters: "Already you have changed/my language, my sleep/ [...] How could you make me want/to change myself so much" (Bhatt 2000, 57-59). The poet shows how a foreign land can snatch everything away from a migrant to signify a double displacement.

During moments of crisis, Bhatt talks about her mother and the memories associated with her. In her "My Mother's Way of Wearing a Sari", the poet charts the duties and responsibilities of Indian women in general through the image of her mother. The figure of her mother in a sari colours her idea of an ideal mother and motherhood. The sari worn by her mother shapes her Indian sensibility, and her mother becomes a representative of the Indian culture and ethos that make her cling to her 'home' away from 'home'. This idea reclaims the fact that home is not bound to a geographical area, but rather is a plastic space, flexible enough to shape into one's sensibility at any latitudinal location. Here Bhatt's concept of home echoes the notion of 'the diasporing of home' given by Avtar Brah, who believes that 
home is a mythic place of desire in the diasporic imagination. In this sense it is a place of no return, even if it is possible to visit the geographical territory that is seen as the place of 'origin'. On the other hand, home is also the lived experience of a locality. (1996, 188-89)

Bhatt's poetry encompasses the concurrent multifarious spatial dimensions of homeland and hostland within the parameters of 'time/space compression' - a term used by Zygmunt Bauman. Displacement creates a pain in Bhatt, but she tries her best to accept the world as it is. She thinks of a world where borders do not create any divide as she focuses on peace, harmony and universalism. She tries to adjust and adapt in the places she goes, and "she adapts to new surroundings in new countries trying to assimilate the best from everywhere" (Namavat 2011, 177). Thus, in the poem "Distances", she writes: "And every place slides/ through my fingers with the filthy/just breaking waves, relentless/salty water" (Bhatt 2001, 100). By taking the freedom of mobility with her poetic corpus, Bhatt's poems set in motion the space-fixing localising definition of home. Here Bhatt's concept of home is shared by Zygmunt Bauman in his study of home and globalisation in our postmodern world:

All of us are, willy nilly, by design or by default, on the move. We are on the move, even if physically we stay put: immobility is not a realistic option in a world of permanent change. Some of us are fully and truly 'global'; some are fixed in their 'locality'- a predicament neither pleasurable nor endurable in a world where the 'globals' set the tone and compose the rules of the life game. $(1998,2)$

Bhatt's notion of diasporic consciousness is personal and collective at the same time, since immigrants often share a collective memory, as noted by William Saffron: "They retain a collective memory, vision, or myth about their original homeland-its physical location, history, and achievements" $(1991,83)$. Triggered by the feelings of loneliness and nostalgia, Bhatt's poetry narrates her memory of the past to acknowledge her homeland. For example, her poem "A Different History" traces the ethos and customs prevalent in India - thinking every tree as sacred, finding gods in monkeys and snakes, showing reverence and godly respect for books, which symbolise the Indian goddess Sarasvati, and thus not touching them with one's feet. At the same time, she does not hold back from attacking the superstitious activities of the ignorant. Expressing her diasporic consciousness coupled with irony, she writes: "You must learn how to turn the pages gently/without disturbing Sarasvati,/without offending the tree/from whose woods the paper was made" (Bhatt 1988, 47).

Bhatt's memories of home do not always depict the factual reproductions of her fixed past, but also "are fluid reconstructions set against the backdrop of the remembering subject's current positionings and conceptualizations of home" (Stock 2010, 24). Femke Stock further says how "contestations of home" and "social ascriptions" (2010, 24) shape an immigrant's conceptualisations to recall the past, interpret the present and orient towards the future. At the same time, notions of prior homes and feelings of being there both physically and metaphorically symbolise belongingness. In the case of Sujata Bhatt, poems like "A Memory from Marathi" and "The Dream" vibrate with her childhood memories to delineate the intricacies of memory and nostalgia that have shaped her complex consciousness. Dreaming of a snake which changes its colour and her father's advice to console her when the snake 
slips out of her reach symbolise two things - first, her childhood memories which erupt into nostalgia while living in the hostland, and second, her reluctant acceptance of a foreign culture, along with its customs and ethos. She has to accept the lived reality of dual identity, and there is no escape from it. Thus, the following lines said by her father in the poem "The Dream" vividly capture her diasporic consciousness: "Don't resist/You must accept it/Then is no point/in fighting with the snake" (Bhatt 2000,15). During this process of creating a dual identity where the homeland becomes a symbol of longing and the hostland is seen "as the object of efforts to belong" (qtd. in Stock 2010, 25), Sujata Bhatt's poetry uses the "empowering paradox of diaspora" (Clifford 1994, 322) to form a fluid and plastic identity, as Femke Stock observes: "The moving between a multiplicity of home spaces, the experience of ambivalently belonging both here and there, can open up new spaces to reflect on and critique essentialist discourses of nation, ethnicity or origin, and to creatively construct new homes and identities that are deemed hybrid, syncretic or fluid" (2010, 26).

Childhood memories of the poet are narrated again in her poem "A Memory from Marathi", which shows her father's killing a snake with a stick and then burning it. The snake symbolises Bhatt's painful memories as an immigrant, and just like the burnt snake she wants to burn off those disturbing images as she writes: "It bled and bled/I could never forget/the redness streaming out/of the broken skin" (Bhatt 2000,20). The blemishes of broken skin ooze out as she erases her torturous consciousness.

Bhatt's diasporic consciousness extends to Indian philosophy and religion in her poem "A Detail from Chandogya Upanishad" that traces the importance of the Sanskrit language and Indian mythologies. So, it can be said that Bhatt's poetry portrays her affection and love for her home, and that her diasporic consciousness in an unceasing and continuous way makes her local experience a global one. Here her diasporic consciousness is marked by "dual or multiple identifications", where her awareness of "de-centred attachments" continuously creates "home away from home, here and there" (Vertovec 2009, 6). She identifies and links herself to more than one society and culture. Through her diasporic consciousness, she not only creates a national identity and culture in her poetry but also imagines a unified nation/ home in her compositions. Exhibiting an awareness of multi-locality and ever-changing spatial dimensions, Bhatt's poetry comes up with "an imaginary coherence" (Hall 1990, 224) for a set of ductile identities - an idea formulated by Stuart Hall. Bhatt's poetry shows how she tries her best to create a transnational identity through her shared imagination, while her notion of displacement creates multiple homes to make a strong connection between her homeland and hostland. Her local images become global when she swiftly moves across continents, and thus her shared space faithfully captures her diasporic consciousness. Her poems remind the readers of what Robin Cohen says:

The central idea is that transnational bonds no longer have to be cemented by migration or by exclusive territorial claims. In the age of cyberspace, a diaspora can, to some degree, be held together or recreated through the mind, through cultural artefacts and through a shared imagination. An identification with a diaspora serves to bridge the gap between the local and global, even if the outcome is a cultural artefact rather than a political project. $(1996,516)$ 


\title{
3 Memory and Nostalgia: Diasporic Consciousness and the Poetry of Debjani Chatterjee
}

\author{
When I left, my eyes caressed \\ each grieving street, each screaming rooftop. \\ The memory of my home \\ Forever burst into my smouldering heart. (Chatterjee et al. 2012, 12)
}

Because of her frequent moving from India to Bangladesh, Japan, Hong Kong, Egypt and Morocco before her final settlement at Sheffield in the UK, Debjani Chatterjee, one of the notable Indian-born British poets, always operates within a multicultural and multilingual framework. Within this pluralistic space, Chatterjee's diasporic consciousness along with issues of marginalisation, memory, nostalgia and estrangement are cleverly explored in a number of volumes of poetry, namely I Was that Woman (1997), Albino Gecko (1998), Animal Antics (2000), Another Bridge (2012), Do You Hear the Storm Sing? (2014), British Raj in the Peak District: Threads of Connection (2015), Spinning a Yarn: Weaving a Poem (2018), and Smiling at Leopards (2018). From her very first volume, memories and histories of Chatterjee's homeland create a connection between her individual and collective past as she intends to construct the notion of 'our homes' - a term used by Vijay Agnew, who observes: "The past is always with us, and it defines our present; it resonates in our voices, hovers over our silences, and explains how we came to be ourselves and to inhabit what we call 'our homes'” $(2005,3)$. Agnew further elaborates on this by telling how an immigrant revisualises, recreates and responds in multifarious ways to construct the 'home' that is left behind. Although different histories, memories, identities, genealogies, and consciousnesses construct contested experience of the past and present, "what we call the past is merely a function and production of a continuous present and its discourses" (McDowell 1989, 147).

In the case of Debjani Chatterjee, the formation of 'our homes' is perceived by her depiction of traumatic discourses of Indian history, especially partition narratives. In the poem "Nazrul" from I Was that Woman, the poet depicts how the partition of India in 1947 not only created a Muslim homeland called Pakistan, but also began the process of inclusion and exclusion of Hindus and Muslims. The poet writes: "you were Muslim, you were Hindu,/a prophet of the Motherland/that breathed so fiercely in your dreams" (Chatterjee 1997, 18). Apart from leaving a lasting impression upon the body and mind of the poet, this political incident not only enables her to memorialise the history of her homeland by creating the idea of a 'homing desire' (Brah 1996, 180), but also relates her to those displaced people whose wounded memories symbolise the impossibility of a return to their homeland. While Dhooleka Raj argues that "partition is remembered and recounted or forgotten and hidden, but sometimes it emerges in specific contexts" $(1998,58)$, Vijay Mishra delineates how the remembrance of displacement disrupts the romantic idealisation of home by making the diasporic individuals aware of it before they formulate a comfortable past: "diasporic imaginary is a particular condition of displacement and disaggregation" and "the postmodern nation-state is a complex socio-economic formation with multiple cultural repertories in which diasporas are always provisionally and problematically inserted" (1996, 442-43). Chatterjee also ruptures 
the romantic affiliations of home in her poem "Home", where her diasporic consciousness compels her to remember "each grieving street, each screaming rooftop" (Chatterjee et al. 2012, 12). The memory is burnt forever into her scrupulous heart that experiences the pangs of a displaced mother who loses everything at the time of partition. The poet persona utters: "This cursed space spawned my one surviving child;/mottled fruit of blasphemy, rare blossom of rape and rage. It nurtures too the wild-eyed orphan/that still suckles at my shrivelled breast" (Chatterjee et al. 2012, 12).

Like the mother, displaced people often find it extremely difficult to stay in an alien land and to rebuild their homes and lives, and even set their temporary accommodation on fire to leave nothing there before their journey towards "home". The poet writes: "This place was only a shelter through the dragging years -/a makeshift pain - it was never home" (Chatterjee et al. 2012 , 12). Thus, imagining the homeland as an alien place, Chatterjee breaks the imposed border in the land created years ago as she wants to re-establish the convoluted ethics of borderland and identity. She believes that "the imagining of the homeland, in a lost desh, particularly bridges the age, class, and economic divide between different sites and waves of migration. Partition and diaspora memories, literary or testimonial, invariably converge on a village or city complicating the meaning of home, nation, and identity" (Roy and Bhatia 2008, xxv). Thus, while living in the UK Chatterjee tries her best to create the ambience of her homeland, and writes poems mentioning the food, culture, customs and ethos of India.

At the same time, the poet delineates how the personal, collective and cultural memories of traumatic events pass down to the 'hinge generation' that not only overwhelmingly inherits those memories, but also grows up realising the effects of the events from the past. This indirect experience is termed 'postmemory' by Marianne Hirsch. The pains of the traumatised history are imagined and further perceived by oral history, photography, documentary and other forms of writing by those who were not directly involved and did not personally experience the horror and trauma. As Hirsch puts it: "Postmemory is a powerful form of memory precisely because its connection to its object or source is meditated not through recollection but through projection, investment, and creation" (1997, 22). Hirsch further says that postmemory serves as a medium "to describe other second-generation memories of cultural or collective traumatic events and experiences" (1997, 22). In her poem "Home", Chatterjee throws light on the impact of partition upon the second or third diasporic generations, especially on children who will also perceive the experience of being displaced from their homeland: "Today, as we turn to face the long march back,/I ache for the cool of welcoming streets and rooftops./But the memory of the place is forever burnt/into my children's eyes and its cinders ignite my fear" (Chatterjee et al. 2012, 13).

Chatterjee's memories of homeland often record histories of events, and she retells those with a difference; this repetition makes the past "a site to struggle over individual and collective memories and memorization" (Hua 2005, 197). In this context, Matt K. Matsuda aptly says: "No history can be pure event, pure evolution; each is rather a repetition, a return to a story which must be retold, distinguished from its previous retelling. The past is not a truth upon which to build, but a truth sought, a re-memorizing over which to struggle" $(1996,16)$. At the same time for Chatterjee, this remembrance and repetition of many traumatic events of 
her homeland make a clear distinction between memory as a medium of nostalgic yearning, and memory as an "archaeology of living memory" - a term used by M. Jacqui Alexander, who notes: "There is a difference between remembering when - the nostalgic yearning for some return - and a living memory that enables us to re-member" $(2002,96)$. Alexander further says how by invoking and excising the past, memory consciously remembers certain narratives to intentionally ponder certain issues.

Chatterjee knowingly portrays certain pictures of her homeland to depict the realities of the present, in order to create awareness and showcase her diasporic consciousness. In her poem "Tagore", she feels pity on seeing the withered condition of Bengal, the land of Rabindranath Tagore. Seeing the socio-political, religious, cultural and economic corruption of modern Bengal, the poet says: "The same society which wore you/Romantic on its sleeve, now withered./In words, like bamboo piercing city/Pollution: struggling, breathing, hunting" (Chatterjee 1997, 17). Visualising and memorialising home as an ideal space where different races and classes can exist peacefully, her poem "Ganapati" necessitates the humanistic demand to embrace people of a different class, caste and religion in her homeland, only to make it a lovely place to stay. As she states: "We saw that we should embrace the children of two races;/ they are the strong links of connection and bear your blessings,/they are rainbows spanning gulfs of silence, swamps of intolerance,/You wanted to stretch our notions of humanity" (Chatterjee 1997, 51). So apart from making the reader aware, Chatterjee's poems also show how the poet carries home with herself.

By depicting her socio-cultural, intellectual and familiar resources in poetry, Chatterjee attempts to construct a personal and social identity in an alien land that remains fractured and fragmented to her perception. She conceives the memory of her homeland as a process through which she shapes "the past into a set of meanings that makes sense" to her poetic corpus in the present, only to necessitate "a recognition of the ways in which this process involves the individual psyche and historically specific public ideologies" (Giles 2002, 24). Giles further says how memories do not act only as the projector and protector of facts, but also formulate meaning. Chatterejee creates a space where home operates as a signifier of security and belonging, as well as a storehouse where the best of her past and present meet. Her poem "The Question" begins like this: "Being Indian, I live abroad/In England, Germany, Disneyland,/Wherever my rainbow spirit beckons" (Chatterjee 1997, 13). While going through "throbbing bazaars" in India, images of "flies and charlatans", "bulls and potbellied banias", oozing sores and gleaming bangles", mud, cow-dung and vermilion remind of her Indianness, and she asks herself: "Am I in this, or is this part of me?/Does the lotus unfold within me,/And am I its muddy bed?" (Chatterjee 1997, 13).

In her poem "Animal Regalia", Chatterjee again talks about her memory which faithfully captures images of halal meat, surma, saris, hunger, Hinduism and a "third world hernia", along with "visas, arranged marriages, immigration,/ethnic monitoring and paraphernalia" (Chatterjee 1997, 20). At the same time, she compares the people coming from India with animals that are exported, as she says: "Elephants, horses, camels come from India,/just like you! came the logical assumption" (Chatterjee 1997, 20). While living in different countries, she constantly creates and recreates the memory of her homeland and thus she continuously 
attempts to make sense of her past in a present that is changing. Her stories become oral narratives, and history is "not just in factual statements but is pre-eminently an expression and representation of culture, and therefore includes not only literal narrations but also the dimension of memory, ideology and subconscious desires" (Passerini 1979, 84). At the same time, Alessandro Portelli defines memory as the non-passive depository of facts as he talks about how the personal involvement of the narrator formulates a standard version of collective memory, and thus narrated stories become the "part of a collective tradition which preserves memory of the group's history beyond the range of the lives of individual members" $(1981,102)$. Chatterjee's "An 'Indian Summer" is one such poem that captures the images of an Indian summer in Sheffield, where she lives in the UK. Narrating on behalf of other immigrants living there, she shows how "the high Himalayas drum with roaring rivers", "the dragonfly flits in the Yorkshire afternoon/while Mandakini descends in roaring waters" (Chatterjee et al. 2012,14) to vividly symbolise Indianness there. Here the mentioning of the River Mandakini, the name of the River Ganges when it flows in Heaven, and the final lines "whenever she is called, Ganga meditates/on Summer rippling the clam of English rivers" (Chatterjee et al. 2012, 14) project how immigrants, like the poet, visualise the image of an Indian summer in an alien land.

While Leo Spitzer defines nostalgia as "the selective emphasis on what was positive in the past" (1999, 153), and McDermott observes that "nostalgia is often seen as a conservative and regressive impulse, a form of escapism in which the past is idealized in contrast to an unsatisfactory present" $(2002,390)$, Gayle Greene thinks that nostalgia, being impulsive and conservative, harks back to the past with a desire to remember, rethink, and recollect certain memories, a view of the past in a foreign country where "they do things differently" (1991, 297). Furthermore, considering the specific meaning of nostalgia from feminist point of view, Greene states: "Nostalgia is not only a longing to return home; it is also a longing to return to the state of things in which women keep the home and in which she awaits, like Penelope, the return of her wandering Odysseus" (1991, 297). Debjani Chatterjee's memories of her homeland and family become the "wandering Odysseus" as in her poem "Namaskar, Sir Walter", she remembers the loving memory of her Dadus - Rai Sahib S N Chatterjee and Sri P N Mukherjee. Here she talks about her paternal and maternal Dadus who live in Timarpur and Mussoorie, and their love of books, travel and history inspire the poet to feel their presence in Edinburgh too. Here the poet's memory urges her to remember and visualise her Dadus in an alien land, and thus she ends the poem by saying: "Having roamed with you in the craggy Highlands, the buzzing Borders,/the great castles and, of course, the regal streets of Edinburgh,/I stand at last before your statue. Namaskar, Sir Walter,/from the bottom of my heart. Please accept these Indian greetings" (Chatterjee et al. 2012, 10).

In another poem, "Reflection", Chatterjee describes a picture of her grandparents, their smart and smiling grandchildren, her shy cousin who is "married now to a business tycoon", her sensible brother who standing at the edge "manages to give the impression/that he is shepherding us children in", her sister's "expression of concentration", her grandmother wearing "a red bordered white sari" and her careful observation of some typical Indian rules (Chatterjee 1997, 45). Apart from all this, she also remembers the game she used to play with her sisters and cousins as she writes: "I remember all the adventures/of that garden just beyond 
the picture frame:/the crocodile and bank game we played,/especially hilarious in monsoon weather" (Chatterjee 1997, 45). While in her poem "My Family" Chatterjee shows how her grandmother's faith and her "children's love and laughter" shape her family (Chatterjee 2014, 9), her poem "Home is Where the Heart is" faithfully captures her diasporic consciousness, her desire to revisit her family in India and her loneliness while staying in an alien land without them. Her grandma's voice seems to echo her thoughts: "Grandma was a bag-packer,/ moving between us siblings./"Daughter, I feel most at home/with my children,' she told me" (Chatterjee 2014, 8). As such, Chatterjee's diasporic sensibilities are coupled with her notion of memory and nostalgia. While putting these personal stories in the public domain via poems, her memories not only imply her present but also share interactive responses where the readers "draw on their own preoccupations, desires, and cultural understanding in order to make themselves at home in the stories they encounter" (Giles 2012, 25). Here Chatterjee's memory links with Graham Dawson's notion of physic composure, where desire, nostalgia, remembrance and displacement are experienced as psychic and social realities. Chatterjee's poems thus deal with Dawson's cultural, social and historiographical epistemologies that emphasise that "an effort towards composure is an inescapably social process. Stories are always told to an audience, actual or imagined, from which different kinds of response and recognition are elicited" (Dawson 1994, 23).

Underpinning the distinction between memory and nostalgia, Annette Kuhn argues that memory-work should be used as "an aid to radicalized remembering [that] can create new understandings of both past and present, while yet refusing a nostalgia that embalms the past in a perfect, irretrievable, moment" $(1995,8)$. Distinguishing nostalgia into two tropes as "restorative and reflexive", Svetlana Boym remarks: "Restorative nostalgia puts emphasis on nostos and proposes to build the lost home and patch up memory gaps. Reflexive nostalgia dwells in algia, in longing and loss, the imperfect process of remembrance" $(2001,41)$. Taking Boym's distinction as the point of departure, Debjani Chatterjee's poems reflect a restorative nostalgia because they reconstruct her past and at the same time emphasise a reflexive nostalgia which "lingers on ruins, the patina of time and history, in the dreams of another place and another time" (Boym 2001, 41). In her poem "Heirlooms", the poet shows how the various ornaments of her $a m m a$, grandma and mother make her nostalgic and compel her to visualise her home. She says: "Golden earring from Ammi,/A pearl necklace from Mummy,/ Old ivory from Granny,/All are memories of home and family" (Chatterjee 2018, 2). In her poem "TriColour", the poet remembers her childhood days when her grandmother wore white, her mother brown and she was dressed in green. While the colour white makes her remember the jasmine flower and the aesthetic beauty of an Indian grandmother, brown symbolises her mother's roots and identity coupled with an Indian sensibility. At the same time, she writes regarding the colour of her dress: "My colour is bright green/like the sugarcane fields/ remembered from childhood" (Chatterjee 2014, 10). These three colours thus make her remember the native land and family there.

In the poem "Home Thoughts" the poet fails to answer the exact time of return to home, "In one sense I never left home, not really;/or at least I am not now the one who left" (Chatterjee 1998, 20). This work marks the beginning of her acceptance of culture, ethos, notions and language of her hostland, and there she formulates her cultural identity that is "a matter of 
becoming and as well as of being" (Hall 1990, 225). In the poem "Learning the Imperialist's Language", the poet says how she slowly learns the coloniser's language as she has nothing to do but to accept it to survive in Sheffield, where people mostly speak English. Regarding her acceptance of this language, she says: "Encountering you was all/the delight of illicit romance" (Chatterjee 1998, 21). Thus, she begins to create her hybrid identities "which are constantly producing and reproducing themselves anew, through transformation and difference" (Hall 1990, 235).

\section{Conclusion}

Through the imagery and symbolic description of homeland, nostalgic memories of families, hybrid identity in the hostland and Indian history, both Sujata Bhatt and Debjani Chatterjee formulate their identities by recalling and sharing a past on the basis of their diasporic consciousness. They conform to Paul Connerton's notion of "acts of transfer" that not only "make remembering in common possible", but also act through "crucial importance, commemorative ceremonies and bodily practices" to lead them to see their "images of the past and recollected knowledge of the past are conveyed and sustained by performances" (Connerton 1989, 39-40). These performances by Bhatt and Chatterjee through 'alternate archives' show how as feminists they use their oral history, rituals, music, visual images, popular and material culture to capture everyday lives, particularly those of excluded, marginalised and disenfranchised populations (Hirsch and Smith 2002, 12). Both these poets construct a cultural memory that is "the product of fragmented personal and collective experience articulated" through their poetry "that shape even as they transmit memory" through the "acts of performance, representation, and interpretation" (Hirsch and Smith 2002, 5).

Through their individual voices and bodies, Bhatt and Chatterjee eschew the homogenising and generalising tropes of diasporic communities, and living in alien lands they portray the consciousnesses that they only develop there. Maurice Halbwachs makes this point clear by saying that "it is in society that people normally acquire their memories. It is also in society that they recall, recognize, and localize their memories" $(1992,38)$. Both these poets carry the images of their homes in their work. Through their stories of homeland and their diasporic consciousness, they give their alien lands a nativity and structure of feeling. Both the poets faithfully submerge in the constituting process of carrying homes on their backs, and thus recreate the local within a global platform which Arjun Appadurai terms as "The production of locality", where "the many displaced, deterritorialized, and transient populations that constitute today's ethnoscapes in the construction of locality, as a structure of feeling, often in the face of the erosion, dispersal, and implosion of neighborhoods as coherent social formations" (Appadurai 1996, 199).

\section{References}

Agnew, Vijay. 2005. Diaspora, Memory, and Identity: A Search for Home. Toronto: University of Toronto Press.

Alexander, M. Jacqui. 2002. "Remembering This Bridge, Remembering Ourselves: Yearning, Memory, and Desire.” In This Bridge We Call Home: Radical Visions for Transformations, edited by Gloria E. Anzaldúa and Analouise Keating, 81-103. New York and London: Routledge. 
Appadurai, Arjun. 1996. Modernity at Large. Minneapolis: University of Minnesota Press.

Bauman, Zygmunt. 1998. Globalzation: The Human Consequences. Cambridge: Polity.

Bhabha, Homi K. 1994. The Location of Culture. London: Routledge.

Bhatt, Sujata. 1988. Brunizem. New York: Carcanet.

-. 1997. Point No Point. Manchester: Carcanet.

-. 2000. Augatora. New York: Carcanet.

-. 2001. Monkey Shadows. New York: Carcanet.

Boym, Svetlana. 2001. The Future of Nostalgia. New York: Basic Books.

Brah, Avtar. 1996. Cartographies of Diaspora: Contesting identities. London: Routledge.

Chatterjee, Debjani. 1997. I was that Woman. Calcutta: Writers Workshop.

-. 1998. Albino Gecho. Salzburg: University of Salzburg.

- 2014. Do You Hear the Storm Sing? Barnsbury: Core Publications.

—. 2018. Smiling at Leopards. Clevedon: The Hedgehog Poetry Press.

Chatterjee, Debjani, Brian D'Arcy, Simon Fletcher, and Basir Sultan Kazmi. 2012. Another Bridge. Sheffield: Sahitya Press.

Clifford, James. 1994. “Diasporas." Cultural Anthropology 9 (3): 302-38. https://doi.org/10.1525/can .1994.9.3.02a00040.

Cohen, Robin. 1996. "Diasporas and the Nation-State: From Victims to Challengers." International Affairs 72 (3): 507-20. https://doi.org/10.2307/2625554

Connerton, Paul. 1989. How Societies Remember. Cambridge: Cambridge University Press.

Dawson, Graham. 1994. Soldier Heroes: British Adventure, Empire, and the Imagining of Masculinities. London: Routledge.

Fortier, Anne-Marie. 2005. "Diaspora." In Cultural Geography: A Critical Dictionary of Key Concepts, edited by David Atkinson et al., 182-87. New York: I. B. Tauris.

Giles, Judy. 2002. "Narratives of Gender, Class, and Modernity in Women's Memories of Mid-Twentieth Century Britain." Signs: Journal of Women in Culture and Society 28 (1): 21-41. https://doi.org/10 $.1086 / 340907$.

Greene, Gayle. 1991. "Feminist Fiction and the Uses of Memory." Signs: Journal of Women in Culture and Society 16 (1): 290-321. https://doi.org/10.1086/494661.

Halbwachs, Maurice. 1992. On Collective Memory. Translated and edited by Lewis Coser. Chicago: Chicago University Press.

Hall, Stuart. 1990. "Cultural Identity and Diaspora." In Identity: Community, Culture, Difference, edited by Jonathan Rutherford, 222-37. London: Lawrence \& Wishart Limited.

Hirsch, Marianne. 1997. Family Frames: Photography, Narrative, and Postmemory. Cambridge, Mass.: Harvard University Press.

Hirsch, Marianne, and Valerie Smith. 2002. "Feminism and Cultural Memory: An Introduction." Signs: Journal of Women in Culture and Society 28 (1): 1-19. https://doi.org/10.1086/340890.

Hoogvelt, A. 1997. Globalization and the Postcolonial World: The New Political Economy of Deelopment. Baltimore: The John Hopkins University Press.

Kuhn, Annette. 1995. Family Secrets: Acts of Memory and Imagination. New York: Verso.

Matsuda, Matt K. 1996. The Memory of the Modern. New York and Oxford: Oxford University Press.

McDermott, Sinead. 2002. "The Gender of Nostalgia: Memory, Nostalgia, and Gender in A Thousand Acres." Signs: Journal of Women in Culture and Society 28 (1): 389-407. https://doi.org/10.1086 1340916.

McDowell, Deborah E. 1989. "Negotiating between Tenses: Witnessing Slavery after Freedom - Dessa Rose." In Slavery and the Literary Imagination, edited by Deborah E. McDowell and Arnold Rampersad, 144-63. Baltimore: The John Hopkins University Press.

Mishra, Vijay. 1996. “The Diasporic Imaginary: Theorizing the Indian Diaspora.” Textual Practice 10 (3): 421-47. https://doi.org/10.1080/09502369608582254.

Nimavat, Dushyant B. 2011. The Cassandras in Exile: A Study of the Diasporic Sensibility in the Poetry of Meena Alexander, Sujata Bhatt, Chitra Banerjee Divakaruni, Moniza Alvi and Jean Arasanayagam. PhD diss., Saurashtra University. https://shodhganga.inflibnet.ac.in/handle/10603/4658. 
Passerini, Lucia. 1979. "Work Ideology and Consensus under Italian Fascism.” History Workshop Journal 8 (1): 82-108. https://doi.org/10.1093/hwj/8.1.82.

Peeran, Esther. 2007. "Through the Lens of the Chronotope: Suggestions for a Spatial-Temporal Perspective on Diaspora." In Diaspora and Memory: Figures of Displacement in Contemporary Literature, Arts and Politics, edited by Marie-Aude Baronian, Stephan Besser and Yolande Jansen, 67-78. The Netherlands: Rodopi.

Portelli, Alessandro. 1981. “The Peculiarities of Oral History.” History Workshop Journal 12 (1): 96-107. https://doi.org/10.1093/hwj/12.1.96

Raj, Dhooleka. 1998. Where Are You From? Middle-Class Migrants in the Modern World. Berkley: University of California Press.

Roy, Anjali Gera, and Nandi Bhatia. 2008. Partition Lives: Narratives of Home, Displacement, and Resettlement. New Delhi: Pearson Longman.

Rutherford, Jonathan. 1990. "Interview with Homi Bhabha: The Third Space." In Identity: Community, Culture, Difference, edited by Jonathan Rutherford, 207-21. London: Lawrence \& Wishart.

Saffron, William. 1991. "Diasporas in Modern Societies: Myths of Homeland and Return." Diaspora: A Journal of Transnational Studies 1 (1): 83-99. https://doi.org/10.1353/dsp.1991.0004.

Spitzer, Leo. 1999. Hotel Bolivia: The Culture of Memory in a Refuge from Nazism. New York: Hill \& Wang.

Stock, Femke. 2010. "Home and Memory." In Diasporas: Concepts, Intersections, Identities, edited by Kim Knott and Seán McLoughlin, 24-28. New York: Zed Books.

Tsagarousianou, Roza. 2004. "Rethinking the Concept of Diaspora: Mobility, Connectivity and Communication in Globalized World." Westminster Papers in Communication and Culture 1 (1): 52-65. https://doi.org/10.16997/wpcc.203.

Vertovec, Steven. 2009. Transnationalism. New York: Routledge.

- 2010. "Cosmopolitanism." In Diasporas: Concepts, Intersections, Identities, edited by Kim Knott and Seán McLoughlin, 63-68. New York: Zed Books. 